\title{
Detection of damage to the power supply system of diesel engine under field conditions
}

Fuel injection system damages is a major problem for internal combustion engines. Approximately $70 \%$ of the injection system malfunction is due to injector damages. Authors of the article tested an uniqe method of diagnosis injectors by using an acoustic emission. The acoustic emission signal (EA) is a phenomenon used in various field of technology and it is a wave generated in solid materials. The EA signal was measured during operation of damaged and undamaged injectors body in a few series, analized and verified in term of result obtain in response signals. The relationship between the acoustic emission signal and the injectors operating phases has been determined. On base of coefficient variation of the duration in the third phase the value of which increases substantially when the injectors are damaged were found in ranges of $45 \%$. For corect working injectors value of coefficient variation were found in range from $21 \%$ to $37 \%$.

Key words: acoustic emissions, common rail, combustion engine, injector diagnostics

\section{Introduction}

Common rail is mostly used in the construction of industrial compression ignition engines. This is one of the ways to meet increasingly stringent criteria for the emission of toxic substances. Common Rail has many advantages that greatly affect engine performance but also has some disadvantages too. In case of inadequate fuel quality, with high precision of system components, it is very susceptible to damage. Injection system damages are major operational problem for any engine, regardless of its brand, application, power or service life. According to research conducted by the authors about $70 \%$ of the injection system malfunction is due to damage to the injectors $[2,5,8]$.

The reason for allowing injectors to work, the abnormal operation of which is not visible in the form of symptoms related to a problematic start-up or a perceptible inadequate operation of the engine is the inability to precisely investigate the technical condition of the injectors at the machine stoppage. As a result, there are emissions of toxic substances to the atmosphere, particulate filter is accelerated filling, power output is reduced and, in many cases, this is sudden and unwanted stopping of the engine $[2,3]$.

\section{Aim of the study}

Adduced arguments on the need for the diagnosis of injectors in real conditions the engine indicate that there is a need to develop a new, noninvasive method that can be applied in the diagnosis of injectors of common rail while the engine is running. The relationship between the signal of acoustic emission and operation phases of the injector is the aim of the study.

\section{Acoustic emission in the diagnosis of combustion engines}

The industry is using the phenomenon of acoustic emission to diagnose the state of facilities and equipment engineering for many years $[1,7,9,11,14-16]$. Acoustic emission (EA) is a passive method and it does not generate additional energy in the test object or it does not interfere with his work. Therefore it is a non-invasive method. The sources of acoustic emission in solid materials are processes that generate and propagate elastic waves in the material $[12,13]$. There is an acoustic emission source signal that reflects the phases of the processes occurring in the Common Rail injectors and it is related to their technical state. The way the technical use of the EA included in ISO 22096, which proposed the use of signal EA for the diagnosis of specified devices, including combustion engines. However, existing methods indication, performed on the engine is running are vague, unreliable and uneconomical.

\section{Stand for experimental research}

The test stand was the diesel engine Perkins whose schematic (including the high pressure circuit) is shown in Figure 1. A diagnostic computer was connected to the engine. Computer monitors selected parameters of its work during the study $[4,6,10]$.

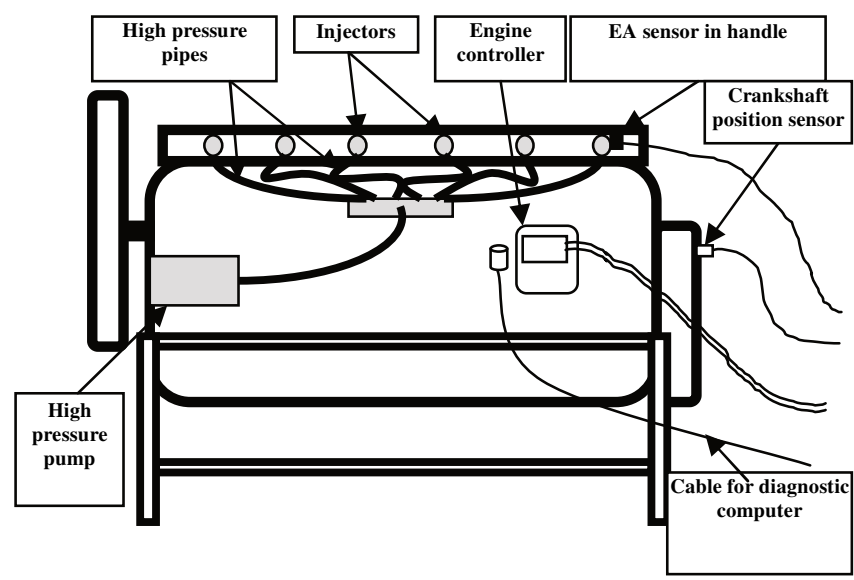

Fig. 1. A simplified diagram of the engine used for testing together with the instrumentation

The basic parameters of the engine used in the tests that are certified according to EU 97/68 / EC Stage IIIA are shown in Table 1. 
Table 1. Basic parameters of the tested engine

\begin{tabular}{|l|c|}
\hline Number of cylinders & \multicolumn{1}{|c|}{$\varnothing 105 \mathrm{~mm}$} \\
\hline Cylinder diameter & $127 \mathrm{~mm}$ \\
\hline Piston stroke & $4400 \mathrm{~cm}^{3}$ \\
\hline Engine capacity & $102 \mathrm{~kW}$ \\
\hline Maximum power at $2200 \mathrm{rpm}$ & $536 \mathrm{Nm}$ \\
\hline Maximum torque at $1400 \mathrm{rpm}$ & $16.2: 1$ \\
\hline Compression ratio & $\begin{array}{c}\text { Turbocharged with end cooling of } \\
\text { the charging air }\end{array}$ \\
\hline Supply system & \\
\hline
\end{tabular}

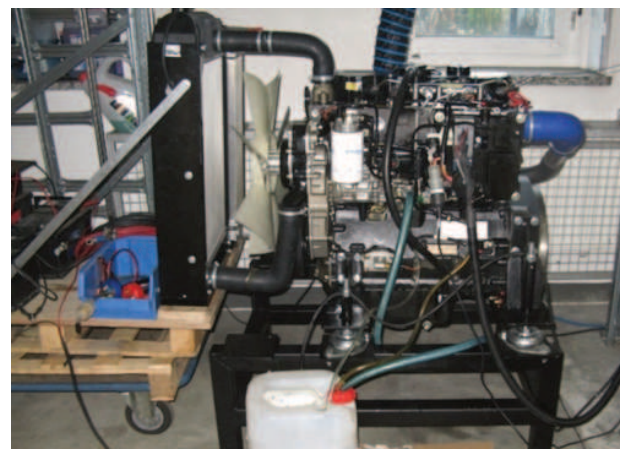

Fig. 2. A view of the PERKINS engine used for experimental research

Each tested injector was mounted on the same cylinder, to achieve a uniform condition during the EA signal measurement for all injectors. The remaining cylinders were fitted with properly functioning, factory-new injectors. The engine was in "perfect" condition (tested, brand new), which allowed us to exclude signals coming from the malfunction of its other functional systems.

The malfunction of most engines can be seen by testing his work at full load. Typical symptoms seen in this way include vibrations, strokes, intermittent work, excessive smoke, lack of power, etc. Those symptoms are usually invisible or impossible to test with the engine idling (while trying engine diagnostics in the field). Therefore, the aim of the research is to diagnose the injector malfunction by means of an acoustic emission already at idle speed of the engine. Detecting anomaly of the injector at idle speed could be done effectively even in the field, at the stoppage of the machine.

An important element of the test is the measurement channel acoustic emission, whose basic elements are shown in Fig. 3.

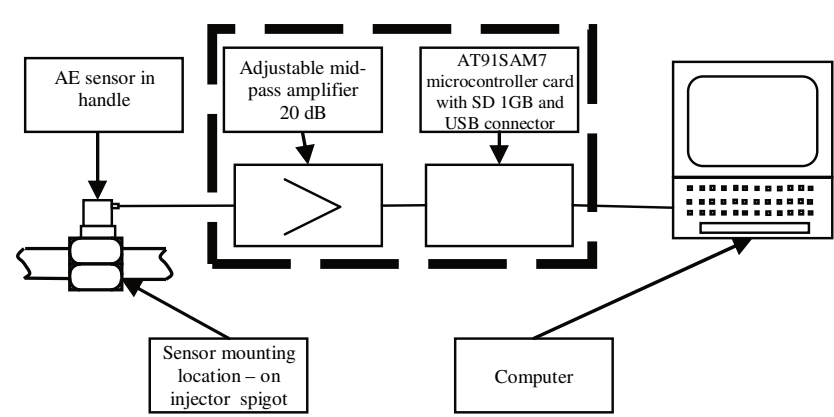

Fig. 3. Simplified schematic of the acoustic emission measurement track

\section{Results of studies}

The best reference point for the EA injection time sequence is the current signal in the injector electrical coil since it is often not possible to use the TDC position sensor on the engine running and the variability of injection maps that depend on the momentary load or conditions environment.

Figure 4 shows the dependence of the measured EA signal with respect to the control signal for the injection process. The injection consists of two phases: Pre-injection and main injection - blue line on the graph. Referring to the principle of the Common Rail (C-R) injector, it is possible to infer what processes in the injector overlap and which ones are reflected in the EA signal.

In Figure 4 the signal of the EA signal that depends on the injector solenoid coil is shown. The coil control signal during the main injection is divided into the coil excitation phase and then the coil spring, which is mainly related to charging the capacitor. On the basis of the analysis of the injection process on the total acoustic emission graph and the injector coil opening current, the following sectors of the injector can be selected (Fig. 4):

- sector A - the injector does not work, the control chamber and the spray chamber are constant pressure, the coil is not energized and the injector is ready for operation;

- sector B - the injector coil is energized, the anchor lift and fuel flow out of the control chamber, then the injector spur is erected and this is the start of the injection process;

- Sector C - the controller switches off the current signal to the coil, the drain choke closes,

- This is the beginning of the pressure equalization process in the control chamber;

- Sector D - the drain choke from the control chamber is closed by the anchor.

CR injector operating sectors
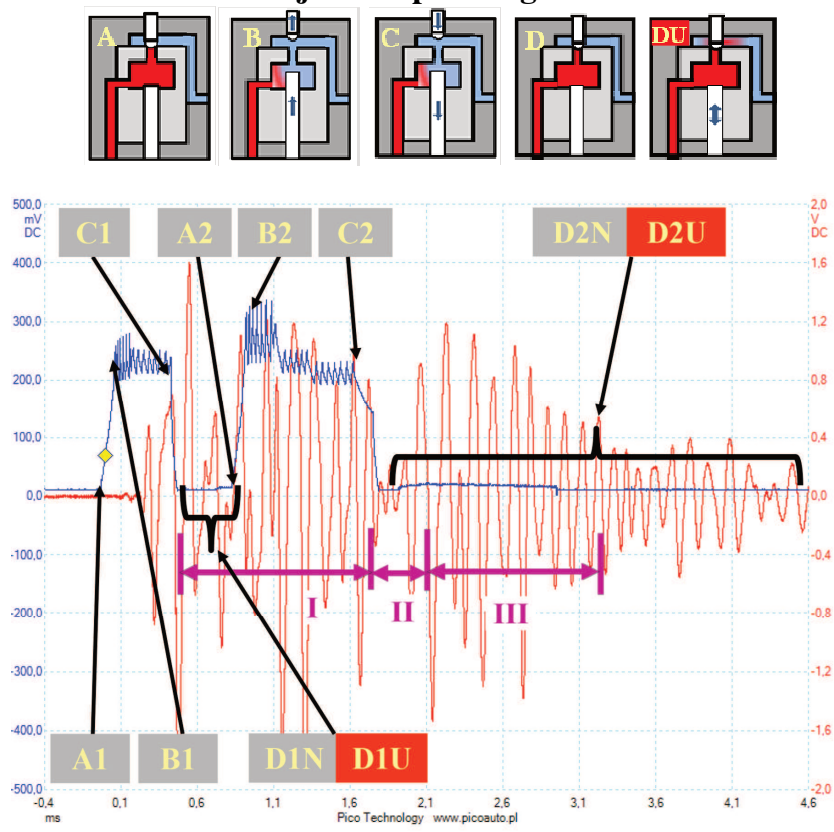

Fig. 4. EA injector signal divide into phases 
In a new injector, the sector marked DN (Sector D New Injector) illustrates the pressure equalization in the control chamber, the needle closure, and the injection end. In a damaged injector, the sector described by the DU symbol (sector D defective injector) shows a leaking control chamber, an overflow to the overflow, a longer fuel pressure stabilization period in the control chamber, and an oscillation of the injector spindle.

The analysis of Fig. 4 allows for two phases forced by the current signal (pre-injection and primary injection) in the working injector. After the response, obtained three basic phases of signal EA (denoted by Roman numerals), which contain the following information:

Phase I - it determinates the value of the signal above the accepted threshold of detection and it contains information from processes pre-injection and the opening of the anchor (the beginning of the injection of basic and closing anchor). In this phase include the sectors A1, B1, C1, D1 and $\mathrm{A} 2, \mathrm{~B} 2$ and $\mathrm{C} 2$ (figure 1 concerns pre-injection, the numeral 2 refers to the basic injection).

Phase II - it is a separate part of the EA signal containing information relating equalizing the pressure in the control chamber. The graph is characterized by low amplitude, because it does not generate the elastic wave originating from striking elements of the injector. Define only the beginning of the sector D2.

Phase III - it illustrates the process of closing the injector needle and it contains most of the sector D2. The duration of this phase depends on the correctness of the closure of the needle and it is generated in the shock of the needle slot elastic waves.

Table 2. Average values of the duration of each phase in the fuel injection signal. $\Delta$ is the coefficient of variation of the parameter under investigation

\begin{tabular}{|c|c|c|c|c|c|c|c|c|c|c|}
\hline \multirow[b]{2}{*}{ Lp. } & \multirow{2}{*}{$\begin{array}{l}\text { Source } \\
\text { signal- } \\
\text { Injector } \\
\text { number }\end{array}$} & \multicolumn{3}{|c|}{$\begin{array}{c}\text { Mean duration of phase I } \\
\text { for } k=60\end{array}$} & \multicolumn{3}{|c|}{$\begin{array}{c}\text { Mean duration of phase II } \\
\text { for } k=60\end{array}$} & \multicolumn{3}{|c|}{$\begin{array}{c}\text { Mean duration of phase } \\
\text { III for } \mathrm{k}=60\end{array}$} \\
\hline & & $\mathrm{t}[\mathrm{ms}]$ & $\begin{array}{c}\text { Standard } \\
\text { deviation } \\
\sigma\end{array}$ & $\Delta[\%]$ & $\mathrm{t}[\mathrm{ms}]$ & $\begin{array}{c}\text { Standard } \\
\text { deviation } \\
\sigma\end{array}$ & $\Delta[\%]$ & $\mathrm{t}[\mathrm{ms}]$ & \begin{tabular}{|c} 
Standard \\
deviation \\
$\sigma$
\end{tabular} & $\Delta[\%]$ \\
\hline 1 & NN1 & 0.86 & 0.07 & 8,66 & 0,48 & 0,31 & \begin{tabular}{|l|}
64,50 \\
\end{tabular} & 0,63 & 0,16 & 24,82 \\
\hline 2 & NN2 & 1.05 & 0.16 & 15,24 & 0,67 & 0,60 & \begin{tabular}{|l|}
89,12 \\
\end{tabular} & 0,60 & 0,14 & 24,05 \\
\hline 3 & NN3 & 0.81 & 0.04 & 5,29 & 03 & 0,78 & \begin{tabular}{|l|}
75,38 \\
\end{tabular} & 0,56 & 0,13 & 23,24 \\
\hline \begin{tabular}{|l}
4 \\
\end{tabular} & NN4 & 0.82 & 0.05 & 5,90 & 0,83 & 0,30 & \begin{tabular}{|l|}
36,14 \\
\end{tabular} & 0,58 & 0,14 & 24,09 \\
\hline 5 & NN5 & 1.12 & 0.14 & 12,07 & 0,45 & 0,26 & \begin{tabular}{|l|}
57,43 \\
\end{tabular} & 0,61 & 0,19 & 31,52 \\
\hline 6 & NN6 & 1.06 & 0.11 & 10,09 & 0,42 & 0,20 & 47,01 & 0,78 & 0,17 & 21,56 \\
\hline 7 & NN7 & 1.03 & 0.18 & 17,91 & 0,46 & 0,75 & \begin{tabular}{|l|}
164,7 \\
\end{tabular} & 0,59 & 0,13 & 22,44 \\
\hline 8 & NN8 & 1.18 & 0.15 & 12,42 & 0,24 & 0,29 & \begin{tabular}{|l|}
123,5 \\
\end{tabular} & 0,86 & 0,20 & 23,77 \\
\hline \begin{tabular}{|l|}
9 \\
\end{tabular} & NN9 & 0.98 & 0.10 & 9,97 & 0,68 & 0,50 & \begin{tabular}{|l|}
73,48 \\
\end{tabular} & 0,58 & 0,17 & 28,78 \\
\hline 10 & NN10 & 1.23 & 0.20 & 15,94 & 0,26 & 0,22 & 84,47 & 0,80 & 0,29 & 35,73 \\
\hline \begin{tabular}{|l}
11 \\
\end{tabular} & NN11 & 0.95 & 0.07 & 7,64 & 0,51 & 0,39 & \begin{tabular}{|l|}
77,20 \\
\end{tabular} & 0,71 & 0,26 & 37,25 \\
\hline 12 & NN12 & 0.89 & 0.08 & 9,38 & 0,90 & 0,64 & \begin{tabular}{|l|}
71,30 \\
\end{tabular} & 0,58 & 0,16 & 27,41 \\
\hline \begin{tabular}{|l|}
13 \\
\end{tabular} & UU1 & 0.98 & 0,26 & 26,09 & 0,18 & 0,43 & 245,8 & 0,87 & 0,42 & 47,86 \\
\hline \begin{tabular}{|l}
14 \\
\end{tabular} & UU2 & 0.96 & 0.14 & 15,11 & 0,49 & 0,55 & \begin{tabular}{|l|}
111,4 \\
\end{tabular} & 0,87 & 0,43 & 49,45 \\
\hline 15 & UU3 & 0.96 & 0.21 & 21,85 & 0,19 & 0,39 & 203,7 & 0,76 & 0,34 & 45,03 \\
\hline \begin{tabular}{|l|}
16 \\
\end{tabular} & UU4 & 0.92 & 0.20 & 21,37 & 0,17 & 0,29 & \begin{tabular}{|l|}
171,6 \\
\end{tabular} & 0,75 & 0,35 & 46,45 \\
\hline 17 & UU5 & 0.82 & 0.04 & 5,18 & 0,74 & 0,77 & \begin{tabular}{|l|}
56,53 \\
\end{tabular} & 0,52 & 0,07 & 14,07 \\
\hline \begin{tabular}{|l|}
18 \\
\end{tabular} & UU6 & 0.89 & 0.16 & 17,79 & \begin{tabular}{|l|}
0,41 \\
\end{tabular} & 0,60 & \begin{tabular}{|l|l}
145,9 \\
\end{tabular} & 0,69 & 0,31 & \begin{tabular}{|l}
44,57 \\
\end{tabular} \\
\hline
\end{tabular}

In order to visualize described above, significant from the point of view of diagnosis phases of the injector, used Look50_60 program, used for direct analysis of signal EA.
Determined durations of the individual phases of the signal produced when the fuel injection are presented in Table 2.

An important parameter is the coefficient of variation of the duration of the third phase, the value of which increases substantially when the injectors are damaged (named UU...) and ranges in the area of $45 \%$. For efficient injectors (named NN...) it ranges from $21 \%$ to $37 \%$. The exception is the UU5 defective injector for which the Phase III variation coefficient adopts an extremely low value, even lower than the new injectors. In case of injuring the injector in the form of seizure of the needle (UU5), after the injection process ends, the impact of the needle is lost at the socket. Due to the constant leakage, the diagnostic tool reads relatively stable signals whose standard deviation is exceptionally low spread. Therefore, in the interpretation of the results, it should be taken into account that the phase variation factor III below $20 \%$ may indicate that the injector is malfunctioning.

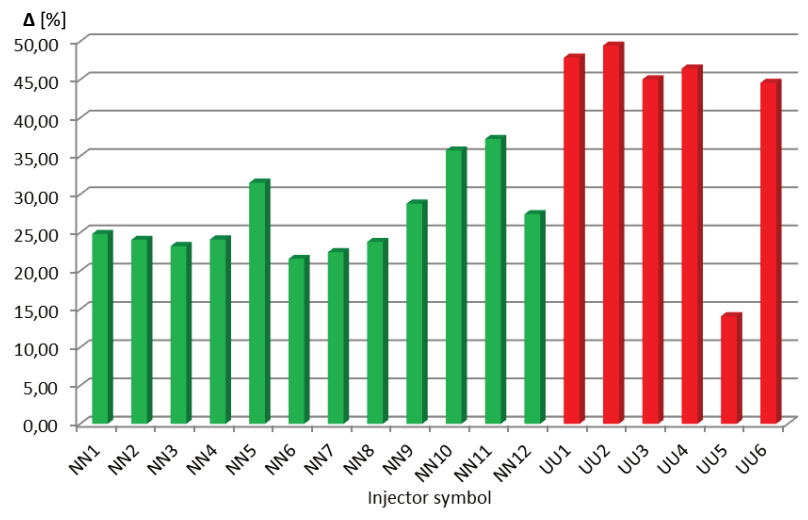

Fig. 5. A summary of the phase-change coefficients of phase III measurements

\section{Spectral density function of the EA signal}

By definition, spectral density is a function of the frequency defined in a set of positive real numbers, which is a set of process execution spectra and is represented in terms of power or energy per unit frequency. When analyzing spectral density charts, significant differences can be observed between spectral density characteristics for undamaged and damaged injectors.

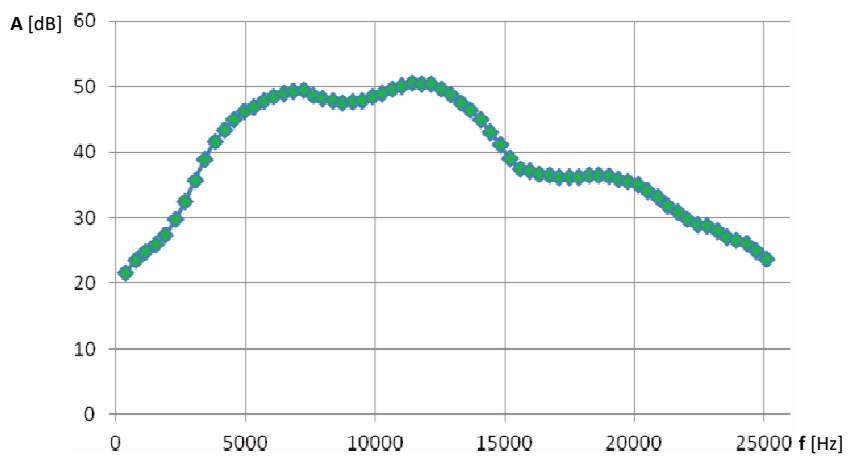

Fig. 6. Mean spectral density values for the new injector NN1-NN12 


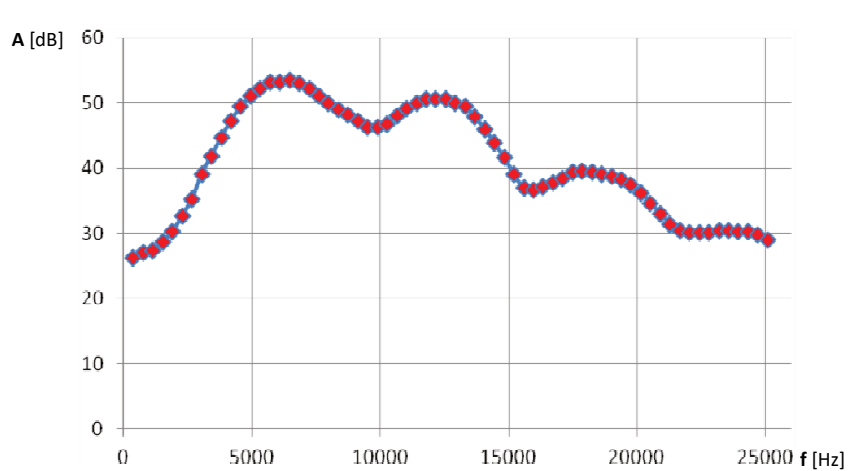

Fig. 7. Mean spectral density values for the set of UU1-UU6 damaged injectors with the exception of UU5

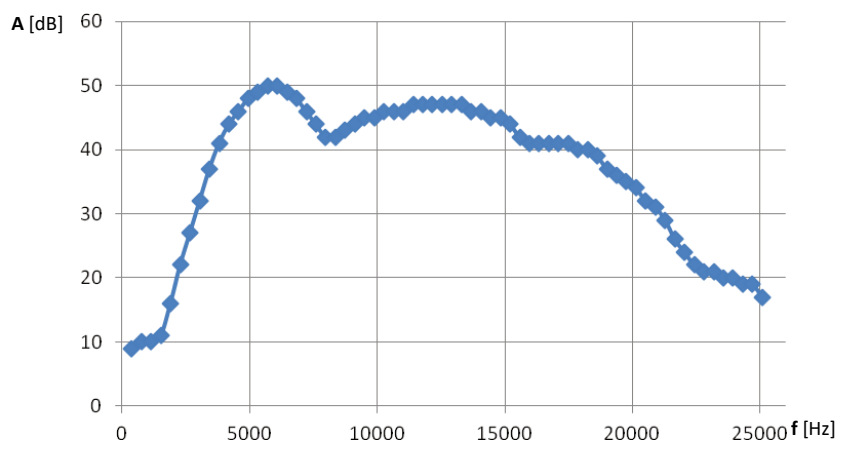

Fig. 8. Spectral density value of the UU5 damaged injector

On the graph of spectral density, the undamaged injectors have two visible maxima, the amplitude of the second being higher than the first and are in the range of 11-12 $\mathrm{kHz}$. Another situation is in the graph of damaged injectors, where is possible to distinguish three distinct and decreas- ing peaks, wherein the first largest is in the range of approx. $6 \mathrm{kHz}$. This begs the conclusion that analyzing the shape of the spectral density on the basis of the read quantity of peaks and locations of the largest peaks can adequately predict the likely state of the injector. The different shape of the curve was determined for the UU5 injector but the feature is the same as for the damaged injectors. The first peak is of the highest amplitude and occurs at around $6 \mathrm{kHz}$.

\section{Conclusions}

The development of any system that improves the accuracy of the diagnosis of the failure of compression-ignition engine components (especially related to its injection system and combustion process) will be of interest to both specialist repair services and engine manufacturers. Analyzing the results of this study it is possible to specify the following conclusions:

1. Operating $\mathrm{CR}$ injectors of compression ignition engines are the source of acoustic emission signals.

2. It is possible to identify and classify injectors into one of two classes of the technical condition: 0 - undamaged, 1 - damaged.

3. There is an acoustic emission source signal that reflects the phases of the processes occurring in the running Common Rail injectors.

4. There is a relation of certain parameters of signal EA from the state of the injector $(0-$ no damage; $1-$ is damaged).

5. It is possible to specify the times of the individual phases of the injector signal produced when the fuel injection.

\section{Nomenclature}

EA acoustic emission

CR Common Rail

\section{Bibliography}

[1] BEJGER, A. Zastosowanie fal sprężystych emisji akustycznej do diagnozowania układów wtryskowych okrętowych silników spalinowych. Wydawnictwo Fotobit. Kraków 2012.

[2] BEJGER, A., MAZURUK, P. Praktyczne sposoby wykrywania niesprawności układów wtryskowych silników Common-Rail. Nadieżnost i Efiektiwnost Tiechniczieskich Sistiem. Mieżdunarodnyj Sbornik Trudow. Kaliningrad 2009.

[3] MAZURUK, P. Diagnostyka zasobnikowych układów paliwowych na podstawie fazowości procesu wtrysku. Rozprawa doktorska. 2013.

[4] MAZURUK, P. Nowoczesne silniki Perkins Tier 4. Zeszyty Naukowe Instytutu Pojazdów. Politechnika Warszawska. 2011, 1(82).

[5] MAZURUK, P. Diagnostyka wtryskiwaczy Common Rail z wykorzystaniem emisji akustycznej. Zeszyty Naukowe Instytutu Pojazdów. Politechnika Warszawska. 2012, 1(87).

[6] ORLIŃSKI, P., WOJS, M.K., MAZURUK, P. Budowa stanowiska do badań paliw eksperymentalnych płynnych wykorzystującego silnik rolniczy o zapłonie samoczynnym.
Zeszyty Naukowe Instytutu Pojazdów. Politechnika Warszawska. 2013, 1(92).

[7] RANACHOWSKI, Z., PAWEŁEK, A., JASIEŃSKI, Z. et al. Durability and wear of engine parts - new methods of testing of alloys and composites. Scientific Journals Maritime University of Szczecin. 2013, 35.

[8] MAZURUK, P., KRUCZYŃSKI, P., ADAMCZYK, H. Wpływ czynników eksploatacyjnych na uszkodzenia nowoczesnych układów paliwowych przemysłowych silników o zapłonie samoczynnym. XXI Ogólnopolskie Sympozjum Naukowe Motoryzacyjne Problemy Ochrony Środowiska. SiMR, Warszawa, 6.12.2013.

[9] OLSZOWSKI, S., MARCZAK, M. Diagnostics of new generation diesel engines. Diagnostyka. 2008, 4(48).

[10] ORLIŃSKI, P, WOJS, M.K., SIKORA, M. Wpływ kąta wyprzedzenia wtrysku na emisję substancji toksycznych $\mathrm{w}$ silniku rolniczym o ZS zasilanym ciekłymi paliwami alternatywnymi. Zeszyty Naukowe Instytutu Pojazdów. Politechnika Warszawska. 2014, 1(97). 
[11] RANACHOWSKI, Z. Metody pomiaru i analiza sygnału emisji akustycznej. Prace IPPT PAN. Warszawa. 1997, 1(11).

[12] RINDORF, H. Acoustic emission source location. Brüel \& Kjaer Technical Review. 1981, 2, 3-32.

[13] Katalog Polskich Norm: PN EN 1330-9:2002 Terminologia: Terminy stosowane w badaniach emisji akustycznej; PN EN 13477-1:2002 Emisja akustyczna. Charakteryzowanie aparatury. Opis aparatury; PN EN 13477-2:2010 Emisja akustyczna. Charakteryzowanie aparatury. Weryfikacja działania; PN EN 13554:2011 Emisja akustyczna. Zasady ogólne.

Paweł Mazuruk, DEng. - Motor Transport Institute

in Warsaw. Engine application Manager in BU

Power Systems Polska/Perkins Poland.

e-mail:Mazuruk.Pawel@gmail.com

Marcin Krzysztof Wojs, DEng. - Faculty of Automotive and Construction Machinery Engineering at Warsaw University of Technology.

e-mail:MWojs@simr.pw.edu.pl
[14] PARMAR, D. Non-destructive bridge testing and monitoring with acoustic emission (AE) sensor technology. Final Report. Hampton University. 2011.

[15] RANACHOWSKI, Z., BEJGER, A. Application of light weight acoustic emission analyzer for diagnostic of the fuel injection system of medium power marine diesel engines. Polish Journal of Environmental Studies. 2009, 18(2A) Supplement.

[16] RAUSCHER, F. Defect detection by acoustic emission examination of metallic pressure vessels. Journal of Acoustic Emission. 2004, 22.

Piotr Orliński, DSc., DEng. - Faculty of Automotive and Construction Machinery Engineering, Warsaw University of Technology.

e-mail:P.Orlinski@simr.pw.edu.pl

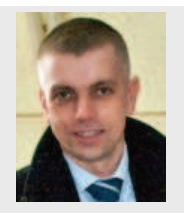

Mieczysław Sikora, MSc. - Faculty of Automotive and Construction Machinery Engineering at Warsaw University of Technology.

e-mail: MSikora@simr.pw.edu.pl 